\title{
Acholeplasma multilocale sp. nov., Isolated from a Horse and a Rabbit
}

\author{
AURIOL C. HILL, ${ }^{1}$ ANNA A. POLAK-VOGELZANG, ${ }^{2}$ AND ALEJANDRO F. ANGULO ${ }^{2 *}$ \\ Toxicology Unit, Medical Research Council Laboratories, Carshalton, Surrey SM5 4EF, \\ United Kingdom, ${ }^{1}$ and National Institute of Public Health and Environment \\ Protection, P.O. Box 1, 3720 BA Bilthoven, The Netherlands ${ }^{2}$
}

\begin{abstract}
Acholeplasma strains were isolated from the nasopharynx of a horse (strain PN525 $^{\mathrm{T}}$ [T $=$ type strain]) and the feces of a rabbit (strain B1). One clone of strain PN525 $^{\mathrm{T}}$ and one clone of strain B1 were examined in detail. These clones were indistinguishable from each other and were serologically distinct from the previously described Acholeplasma and Mycoplasma spp. The strains had the following properties: guanine-plus-cytosine content of $31 \mathrm{mol \%}$; sterol was not required for growth, which occurred under both aerobic and anaerobic conditions; glucose was metabolized; and arginine was hydrolyzed. Strain PN525 (= NCTC 11723) is the type strain of a new species, Acholeplasma multilocale.
\end{abstract}

Mycoplasma colonies were isolated, on a medium used for detection of Mollicutes, from a nasopharyngeal swab taken from a horse. After cloning and preliminary investigation, the isolate was found to consist of a mixture of Acholeplasma oculi and another Mollicutes species (strain PN525 [ $\mathrm{T}=$ type strain]) which could not be further identified. Another strain (strain B1) was isolated from rabbit feces and was identified as an Acholeplasma sp. (2). This strain was cloned from a mixture which contained Acholeplasma laidlawii. The farm where the horse was kept was $30 \mathrm{~km}$ from the breeding unit where the rabbits were kept, and neither the animals nor their caretakers came in contact. In this study the properties of strains PN525 ${ }^{\mathrm{T}}$ and $\mathrm{B} 1$ were further investigated, and these organisms were serologically compared with previously described species.

\section{MATERIALS AND METHODS}

Mycoplasma strains. Mycoplasmas were isolated from the nasopharynx of a horse kept on a farm and from the feces of a rabbit kept at a breeding unit. Small pieces of agar that were obtained from the primary inoculated agar plates and contained single colonies were streaked onto fresh agar plates. After incubation for 4 days, this process was repeated, and after incubation of the resulting plates for 4 days, single colonies were inoculated into broth. After 3 days of incubation, each broth culture was filtered through membrane filters (pore size, $220 \mathrm{~nm}$; (Sartorius, Gottingen, Germany). The resulting filtrate was diluted 10 -fold, and each dilution was inoculated onto agar plates to obtain single colonies. This cloning procedure was repeated once. One clone was designated strain PN525 ${ }^{\mathrm{T}}$ (the clone from the horse), and another clone was designated strain B1 (the clone from the rabbit).

Mycoplasma species. Mycoplasma type strains were obtained from the National Collection of Type Cultures, Colindale, England, and from H. Atobe, M. F. Barile, J. M. Bradbury, R. J. Fallon, E. A. Freundt, J. T. Heywood, F. T. W. Jordan, D. E. Jaspar, H. Kirchhoff, R. H. Leach, G. J. McGarrity, D. L. Rose, G. Smith, D. Taylor-Robinson, and J. G. Tully.

The following Mycoplasma spp. type strains were used:

${ }^{*}$ Corresponding author.
Mycoplasma agalactiae PG2, $M$. alkalescens D12 (= PG51), $M$. alvi Ilsley, $M$. anatis $1340, M$. anseris $1219, M$. arginini G230, $M$. arthritidis PG6, $M$. bovigenitalium PG11, $M$. bovirhinis PG43, M. bovis PG45, M. bovoculi M165/69, $M$. buccale CH-20247, $M$. californicum ST-6, $M$. canadense 275C, $M$. canis PG14, $M$. capricolum California kid, $M$. caviae $\mathrm{G} 122, M$. cavipharyngis $117 \mathrm{C}, M$. citelli $\mathrm{RG}-2 \mathrm{C}, M$. cloacale $383, M$. collis $58 \mathrm{~B}, M$. columbinasale $694, M$. columbinum MMP1, $M$. columborale MMP4, $M$. conjunctivae HRC581, $M$. cricetuli $\mathrm{CH}, M$. cynos $\mathrm{H} 831, M$. dispar 462/2, $M$. edwardii PG24, $M$. ellychniae ELCN-1, $M$. equigenitalium T37, $M$. equirhinis M432/72, $M$. fastidiosum 4822, $M$. faucium DC333, $M$. felifaucium PU, $M$. feliminutum Ben, $M$. felis CO, $M$. fermentans PG18, $M$. flocculare MS42, $M$. gallinaceum DO, $M$. gallinarum PG16, $M$. gallisepticum PG31, M. gallopavonis WR1, M. gateae CS, $M$. genitalium G-37, $M$. glycophilum 486, $M$. hominis PG21, $M$. hyopharyngis $\mathrm{H3}-6 \mathrm{BF}, M$. hyopneumoniae J, M. hyorhinis BTS7, $M$. hyosynoviae S16, $M$. iners PG30, $M$. iowae 695 , $M$. lactucae 831-C4, M. lipofaciens $\mathrm{R} 171, M$. lipophilum MaBy, $M$. luminosum PIMN-1, $M$. lucivorax PIPN-2, $M$. maculosum PG15, M. melaleucae M1, M. meleagridis 17529, M. moatsii MK405, M. mobile 163K, $M$. molare H542, M. muris RIII4, M. mustelae MX9, M. mycoides subsp. capri PG3, $M$. mycoides subsp. mycoides PG1, $M$. neurolyticum Type A, M. opalescens MH5408, $M$. orale $\mathrm{CH}-19299, M$. ovipneumoniae Y98, $M$. oxoniensis $128, M$. pirum HRC70-159, $M$. pneumoniae $\mathrm{FH}, M$. primatum HRC292, M. pullorum CKK, $M$. pulmonis PG34 (= ASH), $M$. putrefaciens $\mathrm{KS}-1, M$. salivarium $\mathrm{PG} 20, M$. somnilux PYAN-1, M. spermatophilum AH159, M. spumans PG13, $M$. sualvi Mayfield (clone B), $M$. subdolum TB, $M$. synoviae WVU1853, M. testudinis 01008, and $M$. verecundum 107.

The following Acholeplasma spp. type strains were used: Acholeplasma axanthum S743, $A$. entomophilum TAC, $A$. equifetale N93, $A$. florum LI, $A$. granularum BTS39, $A$. hippikon $\mathrm{C} 1, A$. laidlawii $\mathrm{PG} 8, A$. modicum $\mathrm{PG} 49, A$. morum 72-043, A. oculi 19L, $A$. parvum H23M, and $A$. seiffertii F7.

Medium and growth conditions. The culture medium which we used has been described previously $(13,30)$. The purified agar used in the growth medium was Lab $\mathbf{M}$ agar (Lab M, London, England). Depending on their biochemical activities, the mycoplasmas were grown in liquid medium containing $1 \%$ (wt/vol) glucose ( $\mathrm{pH} 7.8$ ) or in liquid medium containing 0.5 to $1 \%(\mathrm{wt} / \mathrm{vol})$ arginine $(\mathrm{pH} 7.3)$. The species grew 
in medium containing $1 \%$ arginine and were not inhibited. $M$. genitalium and $M$. synoviae were grown on SP4 medium (35). Strain PN525 ${ }^{\mathrm{T}}$ was isolated and subcultured aerobically on modified Herderscheê medium $(12,22)$. Strain B1 was isolated aerobically on a medium that has been described previously (2) and was subcultured on modified Herderscheê medium. Agar cultures were incubated at 35 to $37^{\circ} \mathrm{C}$ either in a humid chamber or under anaerobic conditions by using a GasPak system (B.D. UK Ltd., Cowley, Oxford, England). Liquid cultures were stored at $-70^{\circ} \mathrm{C}$ in ampoules.

Growth requirements and characteristics. The strains were subcultured onto solid medium and were incubated under both aerobic and GasPak anaerobic conditions at 35 to $37^{\circ} \mathrm{C}$. The levels of susceptibility to methylene blue were determined by adding $0.002 \%$ (wt/vol) methylene blue to the basal solid medium and comparing the growth of inoculated mycoplasmas with the growth of mycoplasmas that were cultivated on agar medium without methylene blue. Lipolytic activity was tested by inoculating mycoplasmas onto basal medium enriched with $10 \%$ egg yolk emulsion (8). The incubated plates were then examined after 3, 7, and 14 days for visual evidence of lipolysis (clearing) or film production.

Absence of reversion. The strains were subcultured for five passages by using both solid and liquid media that contained no microbial inhibitors in order to determine whether the organisms reverted to bacterial forms. Agar culture colonies of each clone were also treated with Dienes stain in order to differentiate mycoplasma colonies from bacterial L-forms (31).

Morphological studies. Mycoplasma colonies grown on agar were examined microscopically at a magnification of $\times 100$ after 2,7 , and 14 days of incubation. The colonies were transferred to slides and stained with Giemsa stain $(9,16)$. Liquid cultures were observed by using dark-field microscopy, and organisms were stained with Giemsa stain (16). Organisms grown in broth were harvested by centrifugation at $30,000 \times g$ for $45 \mathrm{~min}$, and the resulting cell pellet was fixed in $2 \%$ (vol/vol) glutaraldehyde and postfixed in $1 \%$ (wt/vol) osmium tetroxide for $1 \mathrm{~h}$. Thin sections of these preparations embedded in epoxy resin were stained with uranyl acetate and lead citrate and were examined by using electron microscopy (36).

Filtration studies. Cultures (after $24 \mathrm{~h}$ of incubation) were diluted 1:10 in liquid medium and then filtered through a series of membrane filters (Millipore Corp., Bedford, Mass.) with pore diameters of $220,300,450,650$, and $800 \mathrm{~nm}$. The number of colony-forming units per milliliter in each filtrate was determined by plating the preparation onto agar and was compared with the number of colony-forming units per milliliter in the unfiltered culture dilution.

Sterol dependence. Single colonies of strains PN525 ${ }^{\mathrm{T}}$ and B1 were seeded onto serum-free solid media supplemented with $0.5 \%$ bovine serum albumin, $0.5 \%$ glucose, and $10 \mu \mathrm{g}$ of palmitic acid per ml. Cholesterol, dissolved in Tween 80, was added to give concentrations of $20,10,5$, and $1 \mu \mathrm{g} / \mathrm{ml}$. Plates containing no cholesterol were included $(6,7,26,34)$. The mycoplasmas were also subcultured onto the basal agar medium without serum. When growth occurred on any of the serum-free media, single colonies were passaged three times on similar plates to ensure that growth was not due to a carryover of serum from the original culture, avoiding misleading results.

The strains were tested indirectly for sterol dependence by a paper disk inhibition method (10), using wet disks containing $0.02 \mathrm{ml}$ of a $20 \%$ (wt/vol) aqueous solution of sodium polyanethol sulfonate (Koch-Light Laboratories Ltd., Coln-

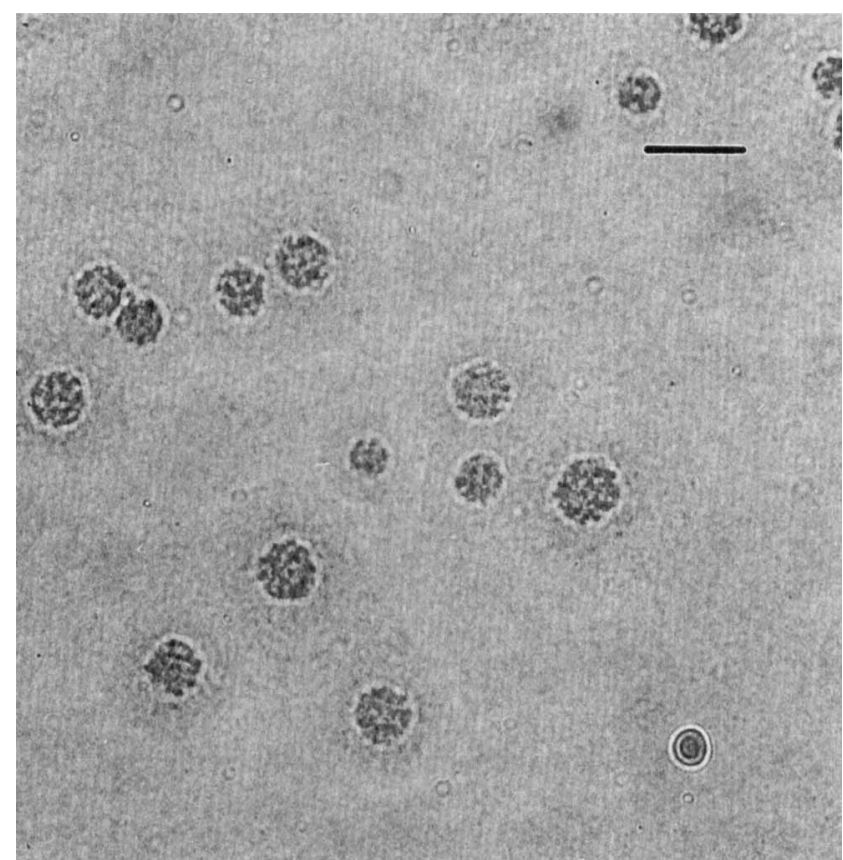

FIG. 1. Colonies of strain PN525 grown under aerobic conditions for 2 days on an agar medium. Bar $=50 \mu \mathrm{m}$.

brook, England) on basal growth medium containing Lab M agar. The widths of zones of growth inhibition were measured.

Digitonin susceptibility. The test to determine susceptibility to digitonin was performed as described by Tully (33), using a paper disk inhibition assay and Herderscheê solid agar containing $20 \%$ serum. A. laidlawii and M. hominis were used as negative and positive controls, respectively.

Production of pigmented carotenoids. Carotenoid production was measured after 5 days of growth in both Chanock and Hederscheê broth media as described by Razin (25). $A$. laidlawii and $A$. axanthum were used as positive and negative controls, respectively.

Biochemical activity. The strains were examined for the following characteristics: metabolism of arabinose, arbutin, cellobiose, dulcitol, fructose, galactose, glucose, glycerol, inositol, lactose, maltose, mannitol, mannose, raffinose, rhamnose, salicin, sorbitol, sucrose, trehalose, and xylose; hydrolysis of esculin, arginine ( 1 and $0.1 \%$ ), and urea; reduction of methylene blue, resazurin, tetrazolium, and tellurite; and phosphatase activity $(1,3,17,28,32,37)$.

Erythrocyte techniques. The strains were examined for hemolytic activity, hemadsorption, and hemagglutination by using chick, guinea pig, and sheep erythrocytes $(1,18)$.

Polyacrylamide gel electrophoresis. Electrophoresis was carried out as described by Mouches and Bové (20), using a one-dimensional slab. Centrifuged cell suspensions were dissolved in a solution containing $20 \%$ glycerol, $5 \% 2$-mercaptoethanol, and $3 \%$ sodium dodecyl sulfate in $0.00625 \mathrm{M}$ Tris buffer (pH 6.8). To a $12.5 \%$ acrylamide gel, $10-$ or $25-\mu 1$ portions of a cell sample were added. Electrophoresis was performed at room temperature for $1 \mathrm{~h}$ at a constant current (20 mA). The gels were stained with Coomassie blue (Sigma Chemical Co., St. Louis, Mo.).

DNA base composition. DNA was extracted from centrifuged broth culture deposits of strain PN525 $5^{\mathrm{T}}$ by using the method of Gross-Bellard et al. (11), and the guanine-plus- 


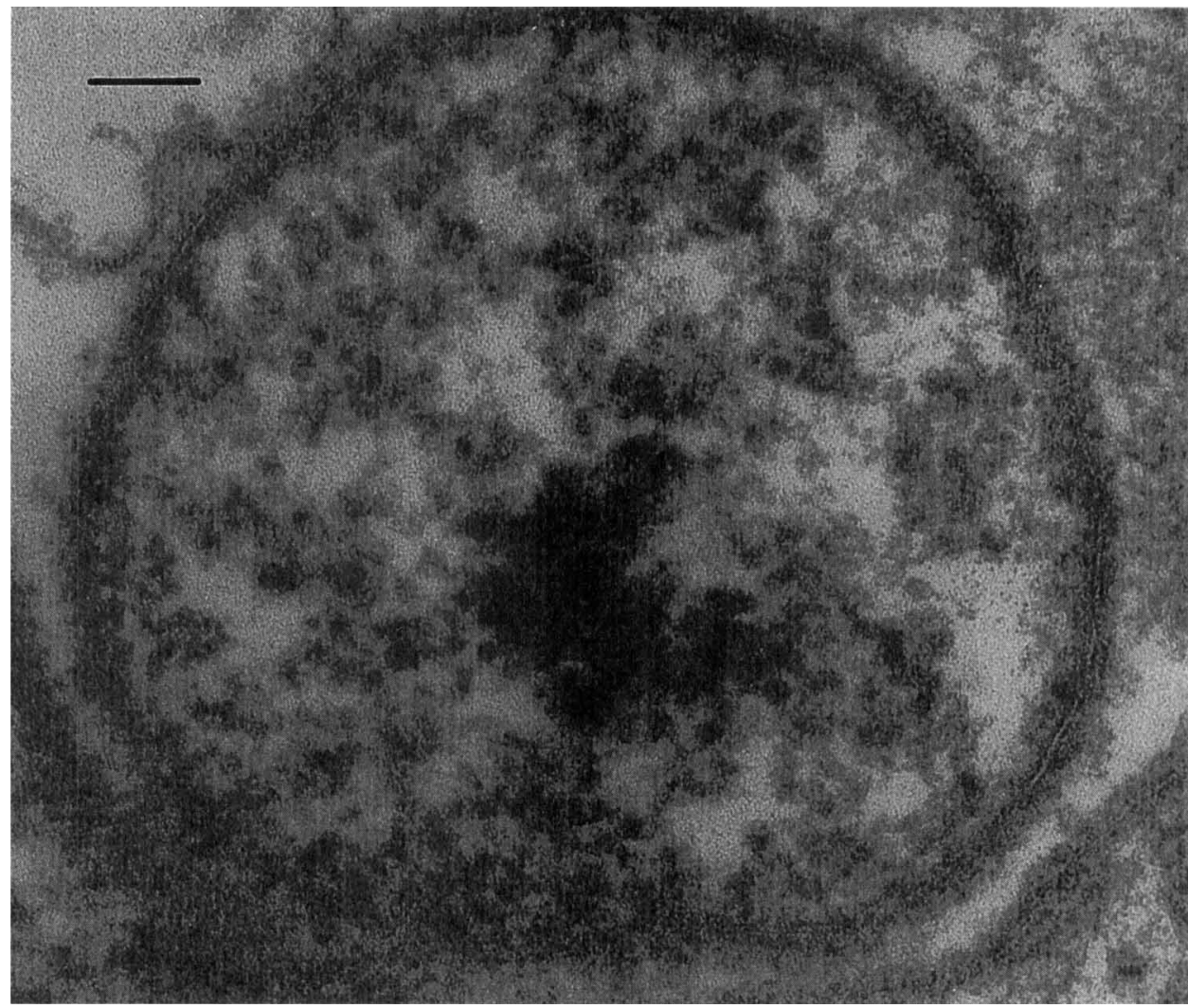

FIG. 2. Electron micrograph of a section of a strain $P N 525^{\mathrm{T}}$ cell stained with uranyl acetate and lead citrate. Bar $=200 \mathrm{~nm}$.

cytosine contents were determined from the buoyant density of the DNA in cesium chloride by ultracentrifugation (27). DNA extracted from Escherichia coli, which had a known guanine-plus-cytosine content, was included as a control.

Serological studies. Antisera were prepared as described by Morton and Roberts (19), Hill (13), and Polak-Vogelzang et al. (21). The following three serological methods were used: growth inhibition tests with antiserum-impregnated sterile paper disks (5), metabolism inhibition tests in microtiter plates $(14,23,24,29)$, and immunoperoxidase tests with colonies grown on agar $(15,21)$. All of the tests were performed in duplicate. Type strain PN525 and strain B1 were reacted with antisera prepared against the species listed above, and antisera to these two strains were tested with the previously described Mycoplasma and Acholeplasma species. Antisera to strains PN525 ${ }^{\mathrm{T}}$ and $\mathrm{B} 1$ were reacted with each other to demonstrate the relationship of these organisms.

\section{RESULTS AND DISCUSSION}

Colonies of strains PN525 $5^{\mathrm{T}}$ and $\mathrm{B} 1$ were visible in subcultures after 4 days of incubation under aerobic and anaerobic conditions. The colonies (Fig. 1) had a typical fried-egg appearance. Growth was not inhibited by methylene blue or on medium without serum. A film was produced on egg yolk agar, but no lipolytic activity was observed. Neither of the strains reverted to a bacterial form when it was subcultured on medium without bacterial inhibitors. The colonies rapidly stained with Dienes reagent, confirming that the isolates were true mycoplasmas (Mollicutes) rather than bacterial L-forms (31).
No motility was observed in fluid media when the strains were examined by using dark-field microscopy, and helical forms were not seen. Preparations from liquid cultures stained with Giemsa stain contained pleomorphic forms characteristic of mycoplasmas. The ultrastructure of the organisms was typical of mycoplasma morphology when thin sections were examined by using electron microscopy (4). The cells were bounded by a single trilaminar unit membrane and lacked any evidence of a cell wall (Fig. 2).

Filtration of a broth culture of strain PN525 ${ }^{\mathrm{T}}$ reduced the viable count from $3 \times 10^{8} \mathrm{CFU} / \mathrm{ml}$ in the original dilution to $2 \times 10^{5} \mathrm{CFU} / \mathrm{ml}$ in the filtrate after passage through a membrane with a pore size of $220 \mathrm{~nm}$.

Strains PN525 $5^{\mathrm{T}}$ and $\mathrm{B} 1$ did not require cholesterol for growth as they could be cultured on medium without cholesterol. They were not susceptible to sodium polyanethol sulfonate. The growth of strain PN525 ${ }^{\mathrm{T}}$ was inhibited by digitonin to $5 \mathrm{~mm}$ from the disk edge, while $A$. laidlawii was inhibited to $3 \mathrm{~mm}$ around the disk edge; the inhibition of $M$. hominis reached more than $10 \mathrm{~mm}$ from the edge.

The production of carotenoids by strain PN $525^{\mathrm{T}}$ was two to three times higher than that by $A$. axanthum but only 50 to $75 \%$ of that by $A$. laidlawii.

The biochemical activities of the strains PN525 $5^{\mathrm{T}}$ and B1 were identical and are summarized in the species description below. In appropriate tests both strains were hemolytic for all three types of erythrocytes tested, but did not hemadsorb these cells. Both strains hemagglutinated the cells which we tested.

The two strains produced similar protein electrophoretic patterns. 
TABLE 1. Serological tests comparing strains PN525 and B1 with previously described species

\begin{tabular}{|c|c|c|c|c|c|c|c|c|c|}
\hline \multirow[b]{2}{*}{ Antigen } & \multicolumn{3}{|c|}{$\begin{array}{l}\text { Growth inhibition zone width (mm) } \\
\text { with antiserum to: }\end{array}$} & \multicolumn{3}{|c|}{$\begin{array}{l}\text { Metabolic inhibition titer with } \\
\text { antiserum to: }\end{array}$} & \multicolumn{3}{|c|}{$\begin{array}{c}\text { Immunoperoxidase titer with } \\
\text { antiserum to: }\end{array}$} \\
\hline & $\begin{array}{l}\text { Strain } \\
\text { PN525 }\end{array}$ & $\begin{array}{l}\text { Strain } \\
\text { B1 }\end{array}$ & $\begin{array}{c}\text { Previously } \\
\text { described } \\
\text { species }\end{array}$ & $\begin{array}{l}\text { Strain } \\
\text { PN525 }^{\mathrm{T}}\end{array}$ & $\begin{array}{c}\text { Strain } \\
\text { B1 }\end{array}$ & $\begin{array}{c}\text { Previously } \\
\text { described } \\
\text { species }\end{array}$ & $\begin{array}{l}\text { Strain } \\
\text { PN525 }\end{array}$ & Strain B1 & $\begin{array}{c}\text { Previously } \\
\text { described } \\
\text { species }\end{array}$ \\
\hline PN525 ${ }^{\mathrm{T}}$ & 3 & 5 & 0 & 8,000 & 64,000 & $<100$ & 4,000 & $>16,000$ & $<100$ \\
\hline B1 & 3 & 5 & 0 & 2,048 & 32,000 & $<100$ & 4,000 & $>16,000$ & $<100^{a}$ \\
\hline $\begin{array}{l}\text { All previously described } \\
\text { species }\end{array}$ & 0 & 0 & & $<100$ & $<100$ & & $<100$ & $<100$ & \\
\hline
\end{tabular}

${ }^{a}$ Strain B1 antigen produced a one-way cross-reaction with $M$. verecundum antiserum in the immunoperoxidase test.

The guanine-plus-cytosine content of strain PN525 $5^{\mathrm{T}}$ DNA was determined from its buoyant density in cesium chloride to be $31 \mathrm{~mol} \%$. This value is within the range of values for previously characterized Acholeplasma species.

The serological techniques which we used revealed similar levels of cross-reactivity between strains PN525 ${ }^{\mathrm{T}}$ and $\mathrm{B} 1$ (Table 1). No significant cross-reactions were detected with any of the species listed in Materials and Methods, except for a one-way cross-reaction with $M$. verecundum antiserum in the immunoperoxidase test. However, $M$. verecundum belongs to a different genus than strains PN525 $5^{\mathrm{T}}$ and B1.

Strains PN525 ${ }^{\mathrm{T}}$ and B1 belong to the family Acholeplasmataceae because of their main characteristics, including absence of cell walls, lack of reversion to bacterial forms when the organisms are grown in antibiotic-free media, penicillin resistance, filterability, and production of typical morphology on agar. They belong to the genus Acholeplasma because they are not strict anaerobes (in contrast to Anaeroplasma spp.), are non-helical (in contrast to Spiroplasma spp.), and do not depend on sterol for growth (in contrast to Mycoplasma spp.) and because the presence of urease activity could not be demonstrated (in contrast to Ureaplasma spp.).

Strains PN525 $5^{\mathrm{T}}$ and $\mathrm{B} 1$ belong to the same species as they have identical biological characteristics and produce identical serological and protein patterns. As they are distinct from all previously described Acholeplasma spp. (see above), strains $\mathrm{PN} 525^{\mathrm{T}}$ and $\mathrm{B} 1$ belong to a new Acholeplasma species.

Description of Acholeplasma multilocale sp. nov. Acholeplasma multilocale (mul.ti.lo.ca'le. M.L. gen. multilocale, referring to more than one location).

Morphological and physical characteristics. Pleomorphic cells are bounded by a single unit membrane. Colonies on agar have a typical fried-egg appearance. Organisms are filterable through 220-nm-pore-size membrane filters and are resistant to penicillin.

Growth characteristics. Does not require sterol. Optimal growth occurs at 35 to $37^{\circ} \mathrm{C}$ under aerobic or anaerobic conditions. A film is produced on egg yolk agar.

Metabolic characteristics. Glucose, fructose, maltose, mannose, and sucrose are metabolized; arginine is hydrolyzed; resazurin, methylene blue, and tellurite are reduced.

DNA base composition. The DNA base composition is 31 mol\% guanine-plus-cytosine.

Habitat. Isolated from a horse nasopharynx and rabbit feces.

Type strain. The type strain is strain PN525 (= NCTC 11723).

\section{ACKNOWLEDGMENTS}

We thank A. Brammall for supplying the photographs, G. P. Stalley for evaluating the DNA base composition, and J. G. Tully and D. Rose for some comparative serology.

\section{REFERENCES}

1. Aluotto, B. B., R. G. Wittler, C. O. Williams, and J. E. Faber. 1970. Standardized bacteriologic techniques for the characterization of Mycoplasma species. Int. J. Syst. Bacteriol. 20:35-58.

2. Angulo, A. F., M. Doeksen, A. C. Hill, and A. A. PolakVogelzang. 1987. Isolation of Acholeplasmatales from rabbit faeces. Lab. Anim. 21:201-204.

3. Barber, T. L., and J. Fabricant. 1971. Identification of Mycoplasmatales: characterization procedures. Appl. Microbiol. 21: 600-605.

4. Boatman, E. S. 1979. Morphology and ultrastructure of Mycoplasmatales, p. 63-102. In M. F. Barile and S. Razin (ed.), The mycoplasmas, vol. 1. Academic Press, Inc., New York.

5. Clyde, W. A., Jr. 1964. Mycoplasma species identification based upon growth inhibition by specific antisera. J. Immunol. 92:958-965.

6. Edward, D. G. fi. 1971. Determination of sterol requirement for Mycoplasmatales. J. Gen. Microbiol. 69:205-210.

7. Edward, D. G. ff., and W. A. Fitzgerald. 1951. Cholesterol in the growth of organisms of the pleuropneumonia group. J. Gen. Microbiol. 5:576-586.

8. Fabricant, J., and E. A. Freundt. 1967. Importance of extension and standardization of laboratory tests for the identification and classification of mycoplasma. Ann. N.Y. Acad. Sci. 143:50-58.

9. Fallon, R. J., and P. Whittlestone. 1969. Isolation, cultivation and maintenance of mycoplasmas. Methods Microbiol. 3B:211267.

10. Freundt, E. A., B. E. Andrews, H. Ernø, M. Kunze, and F. T. Black. 1973. The sensitivity of Mycoplasmatales to sodiumpolyanethol sulfonate and digitonin. Zentralbl. Bakteriol. Parasitenkd. Infektionskr. Hyg. Abt. 1 Orig. Reihe A 225:104-112.

11. Gross-Bellard, M. J., P. Oudet, and P. Chambon. 1973. Isolation of high molecular weight DNA from mammalian cells. Eur. J. Biochem. 36:32-38.

12. Herderscheê, D. 1963. An improved medium for isolation of the Eaton agent. Antonie van Leeuwenhoek 29:154-156.

13. Hill, A. C. 1971. Mycoplasma caviae, a new species. J. Gen. Microbiol. 65:109-113.

14. Hill, A. C. 1977. The metabolic inhibition test for mycoplasmas based on phosphatase production. J. Hyg. 79:391-393.

15. Hill, A. 1978. Demonstration of mycoplasmas in tissue by the immunoperoxidase technique. J. Infect. Dis. 137:152-154.

16. Klieneberger-Nobel, E. 1962. Morphology of pleuropneumonialike organisms, p. 23-56. In E. Klieneberger-Nobel (ed.), Pleuropneumonia-like organisms (PPLO) Mycoplasmataceae. Academic Press, Inc., New York.

17. Leach, R. H. 1976. The inhibitory effect of arginine on growth of some mycoplasmas. J. Appl. Bacteriol. 41:259-264.

18. Manchee, R. J., and D. Taylor-Robinson. 1968. Haemadsorption and haemagglutination by mycoplasmas. J. Gen. Microbiol. 
50:465-478.

19. Morton, H. E., and R. J. Roberts. 1967. Production of antimycoplasma (PPLO) antibodies in rabbits. Proc. Soc. Exp. Biol. Med. 125:538-543.

20. Mouches, C., and J. M. Bové. 1983. Electrophoretic characterization of mycoplasma proteins. Methods Mycoplasmol. 1:241255.

21. Polak-Vogelzang, A. A., R. Hagenaars, and J. Nagel. 1978. Evaluation of an indirect immunoperoxidase test for identification of Acholeplasma and Mycoplasma. J. Gen. Microbiol. 106:241-249.

22. Polak-Vogelzang, A. A., R. Reijgers, and F. E. N. Hekkens. 1980. Isolation of Mycoplasma hyorhinis and Mycoplasma fermentans from cell cultures. J. Biol. Stand. 8:243-254.

23. Purcell, R. H., D. Taylor-Robinson, D. C. Wong, and R. $M$. Chanock. 1966. A color test for the measurement of antibody to the non-acid-forming human mycoplasma species. Am. J. Epidemiol. 84:51-66.

24. Purcell, R. H., D. Taylor-Robinson, D. C. Wong, and R. M. Chanock. 1966. Color test for the measurement of antibody to T-strain mycoplasmas. J. Bacteriol. 92:6-12.

25. Razin, S. 1983. Pigmented carotenoids. Methods Mycoplasmol. 1:375-376.

26. Razin, S., and J. G. Tully. 1970. Cholesterol requirement of mycoplasmas. J. Bacteriol. 102:306-310.

27. Schildkraut, C. L., J. Marmur, and P. Doty. 1962. Determination of the base composition of deoxyribonucleic acid from its buoyant density in CsCl. J. Mol. Biol. 4:430-443.
28. Shepard, M. C., and D. R. Howard. 1970. Identification of " $T$ " mycoplasmas in primary agar cultures by means of a direct test for urease. Ann. N.Y. Acad. Sci. 174:809-819.

29. Taylor-Robinson, D., R. H. Purcell, D. C. Wong, and R. M. Chanock. 1966. A colour test for the measurement of antibody to certain mycoplasma species based upon the inhibition of acid production. J. Hyg. 64:91-104.

30. Taylor-Robinson, D., M. H. Williams, and D. A. Haig. 1968. The isolation and comparative biological and physical characteristics of T-mycoplasmas of cattle. J. Gen. Microbiol. 54:33-46.

31. Timms, L. 1967. Isolation and identification of avian mycoplasmas. J. Med. Lab. Technol. 24:79-89.

32. Tully, J. G. 1965. Biochemical, morphological and serological characterization of mycoplasma of murine origin. J. Infect. Dis. 115:171-185.

33. Tully, J. G. 1983. Tests for digitonin sensitivity and sterol requirements. Methods Mycoplasmol. 1:355-357.

34. Tully, J. G., and S. Razin. 1969. Characteristics of a new sterol non-requiring mycoplasma. J. Bacteriol. 98:970-978.

35. Tully, J. G., R. F. Whitcomb, H. F. Clark, and D. L. Williamson. 1977. Pathogenic mycoplasmas: cultivation and vertebrate pathogenicity of a new spiroplasma. Science 195:892-894.

36. Venable, J. H., and R. Coggeshall. 1965. A simplified lead citrate stain for use in electron microscopy. J. Cell Biol. 25:407-408.

37. Williams, C. O., and R. G. Wittler. 1971. Hydrolysis of esculin and phosphatase production by members of the order $\mathrm{Myco}-$ plasmatales which do not require sterol. Int. J. Syst. Bacteriol. 21:73-77. 